\title{
Analysis of Physico-chemical Characteristics of Soil from Various Locations of Banda City, Uttar Pradesh, India
}

\section{Arvind Prasad Dwived}

Lecturer, Department of chemistry, Govt. Sanjya Gandhi Smrati Auto P.G. College Sidhi M.P., India.

\begin{abstract}
Banda is geographically located at coordinated $25.29^{\circ} \mathrm{N}$ latitude \& $80.20^{\circ}$ longitude total area 4,413 $\mathrm{km}^{2}$ and population 19, 79,541 censuses (2011) of Banda District. Sampling was done during summer season of April month 2015. Various physico- chemical parameter of each location were analyzed by different technique. The samples were analyzed for Heavy metals using atomic absorption spectrometer. . It can be concluded that the physico-chemical analysis of soil samples under study showed variable concentration of various parameters.
\end{abstract}

Keywords: Physico-chemical Parameters, Soil, Banda City, Uttar Pradesh

\section{INTRODUCTION}

Banda, the easternmost district of Bundelkhand in Uttar Pradesh state. It is the district headquarters, and a part of Chitrakoot division. Banda is geographically located at coordinated $25.29^{\circ} \mathrm{N}$ latitude \& $80.20^{\circ}$ longitude total area $4,413 \mathrm{~km}^{2}$ and population 19, 79,541 censuses (2011) of Banda District. Banda having four Tehsils Nairani, Baberu, Attara, Pailani and eight blocks. Agriculture with the main crops being Paddy rice, wheat and vegetable. Banda is a town of religious culture, historical and archaeological importance situated in the Bundelkhand region. Banda languages are bundeli which has a lexical similarity of $72-91 \%$ with Hindi. ${ }^{[1]}$

Generally top soil layer contain largest amount of pollutants. The contamination concentration in soil depends on the adsorption properties of soil matter its properties determined by organic matter. Variation of organic matter may be the predominant cause of variation in environment concentration in soil. ${ }^{[2]}$ Environment factors such as land use temperature rainfall etc can artificially change organic matter content as well heavy metals concentration in soil. The solubility of heavy metal ions in soil was mainly influence by many factors such $\mathrm{pH}$, Conductivity, etc. ${ }^{[3]}$ Heavy metals occur naturally in the ecosystem with large variations in concentration. In modern times, anthropogenic sources of heavy metals, i.e. pollution, have been introduced to the ecosystem.

The metal contents have been shown to be essential for plants, and lower forms of animal life and even other mammals, the yield of crop depends on fertility and presence of micronutrients and heavy metals in the soil. The soil condition is of great importance, because it is a universal medium for plant growth, which supplies essential nutrients to the plants. ${ }^{[4]}$

\section{Material ANd Methods}

Sampling was done during summer season of April month 2015. Fifteen soil samples were collected from different location in plastic bags, dried at $60^{\circ}$ for 48 hours and fine powder was made up with the help of pistil mortar and sieved it with $2 \mathrm{~mm}$ sieve. Various physico- chemical parameter of each location were analyzed by different technique ${ }^{[5]}$.

\subsection{Digestion of Soil Samples for Heavy Metal Analysis}

Sieving of the soil was completed with the help of $0.5 \mathrm{~mm}$ sieves and was dried for 24 hours after drying it was made cool at room temperature. After drying soil was digested with nitric acid and distilled water. The samples were analyzed for Heavy metals using atomic absorption spectrometer ${ }^{[6]}$. The locations of sampling station are shown in table 1 . 
Table1. List of sampling station in Banda city

\begin{tabular}{|l|l|l|c|}
\hline \multicolumn{1}{|c|}{ Sampling Location } & \multicolumn{1}{c|}{ So. } & \multicolumn{1}{|c|}{ Sampling Area } & Depth in cm. \\
\hline 1 & Union bank of India chhawni $\left(\mathrm{BRS}_{1}\right)$ & Residential area & $15 \mathrm{~cm}$. \\
\hline 2 & District stadium civil line $\left(\mathrm{BRS}_{2}\right)$ & Residential area & $15 \mathrm{~cm}$. \\
\hline 3 & Maheswaridevimandir $\left(\mathrm{BRS}_{3}\right)$ & Residential area & $15 \mathrm{~cm}$. \\
\hline 4 & Babulalchok $\left(\mathrm{BRS}_{4}\right)$ & Residential area & $15 \mathrm{~cm}$. \\
\hline 5 & Pt. J.N. College $\left(\mathrm{BRS}_{5}\right)$ & Residential area & $15 \mathrm{~cm}$. \\
\hline 6 & Power house sarvodayanagar $\left(\mathrm{BRS}_{6}\right)$ & Residential area & $15 \mathrm{~cm}$. \\
\hline 7 & Lokeshkirana store chauk bazaar $\left(\mathrm{BRS}_{7}\right)$ & Residential area & $15 \mathrm{~cm}$. \\
\hline 8 & Chillaghat $\left(\mathrm{BCS}_{1}\right)$ & Commercial area & $15 \mathrm{~cm}$. \\
\hline 9 & Naraini $\left(\mathrm{BCS}_{2}\right)$ & Commercial area & $15 \mathrm{~cm}$. \\
\hline 10 & Ladkapurwa $\left(\mathrm{BCS}_{3}\right)$ & Commercial area & $15 \mathrm{~cm}$. \\
\hline 11 & Kalyanpur $\left(\mathrm{BCS}_{4}\right)$ & Commercial area & $15 \mathrm{~cm}$. \\
\hline 12 & Jaspura $\left(\mathrm{BCS}_{5}\right)$ & Commercial area & $15 \mathrm{~cm}$. \\
\hline 13 & Bisandakhurd $\left(\mathrm{BCS}_{6}\right)$ & Commercial area & $15 \mathrm{~cm}$. \\
\hline 14 & Dingwahi $\left(\mathrm{BCS}_{7}\right)$ & Commercial area & $15 \mathrm{~cm}$. \\
\hline
\end{tabular}

\section{RESUlT AND DISCUSSION}

Physico-chemical characteristic of soil collected from different areas of Banda City and all the results are shown in table 2.

\subsection{Temp, pH and EC}

The temperature of soil greatly affects the physicals bio logical and chemicals process occurring in soil temperature plays a very important role in soil characteristics and seed germination. Temperature regenerates nutrients ion in higher plants. In the present study temperature value was observed between $25.7{ }^{\circ} \mathrm{C}$ to $33.4{ }^{\circ} \mathrm{C}$. The highest temperature was recorded in $33.4{ }^{0} \mathrm{C}$ at District stadium civil line $\left(\mathrm{BRS}_{2}\right)$ and lowest $25.7^{\circ} \mathrm{C}$ at Babulalchauk $\left(\mathrm{BRS}_{4}\right)$. (Tripathi et al. 2014) ${ }^{[7]}$ Studies of Physico chemical characteristics of soil in Shahdol District of Vindhya platue and reported the temperature was observed to be $28.64{ }^{\circ} \mathrm{C}$ to $42.28{ }^{\circ} \mathrm{C}$. The measurement of $\mathrm{pH}$ shows the acidity and alkalinity of the soil. PH concentration of all the soil samples varied from 6.38 to 7.8. The highest $\mathrm{pH}$ is observed 7.8 at sampling location Chillaghat $\left(\mathrm{BCS}_{1}\right)$ and minimum value 6.38 at Babulalchauk $\left(\mathrm{BRS}_{4}\right)$. The measurement of electrical conductivity is for measure the current that gives a clear idea of soluble soil present in the soil. Conductivity depends upon the dilution of soil suspension. The highest EC is recorded in sampling station at 0.10 Lokeshkirana store chauk bazaar $\left(\mathrm{BRS}_{7}\right)$ to $0.92 \mathrm{mhos} / \mathrm{cm}$ at Ladkapurwa $\left(\mathrm{BCS}_{3}\right)$. (Mandal et al. 2010) ${ }^{[8]}$ studied Nagpur soil and recorded EC 0.21 to 0.49 mhos/cm.

\subsection{Nitrogen, Phosphorous and Potassium}

Nitrogen is the most fertilizers element. Plant responds quickly to application of nitrogen. This element encourages above ground vegetative growth and gives a deep green colour to the leaves. Plants roots take up nitrogen in the form of $\mathrm{NO}_{3}$ and $\mathrm{NH}_{4}$. In the present study showed higher amount of nitrogen 29.5 at Bisandakhurd $\left(\mathrm{BCS}_{6}\right)$ while 5.1 at District stadium civil line $\left(\mathrm{BRS}_{2}\right)$ show less amount of nitrogen. The over increase in $\mathrm{N}_{2}$ is due to the use of fertilizers which contains high amount of $\mathrm{N}_{2}$. The phosphorous is a part of every living cell in plant. The every activity of plant such as growth respiration and reproduction depends upon phosphorous levels. Maximum amount of available phosphorus .75 at site Naraini $\left(\mathrm{BCS}_{2}\right)$.Potassium is the third essential fertilizer element. Potassium is essential for photo syntheses for protein synthesis, starch formation and for the translocation of sugars. This is important for grain formation and development. All the root crops are generally give response to application of potassium. In the current study shows $42 \mathrm{mg} / \mathrm{kg}$ higher amount in sampling station Maheswaridevimandir $\left(\mathrm{BRS}_{3}\right)$. (Tripathi et al. 2014) ${ }^{[9]}$ studied concentration of $\mathrm{Cr}, \mathrm{Pb}, \mathrm{Cd}, \mathrm{Ni}, \mathrm{Cu}$ and $\mathrm{Fe}$ in soil of Umaria District, Vindhya Platue, India and reported $\mathrm{N}, \mathrm{P}, \mathrm{K}$ are found to be 8.86 to $41.50 \mathrm{mg} / \mathrm{kg}, 0.25$ to $1.16 \mathrm{mg} / \mathrm{kg}, 30$ to $70 \mathrm{mg} / \mathrm{kg}$.

\subsection{Heavy Metal Content of Soil}

The heavy metal concentration in the soil sample of Banda district with their means, standard deviations and coefficient variant are presented in table 2 . The present investigation of the total content of heavy metals in the soil was restricted to the top. The mean concentration of $\mathrm{Pb}$ was ranging between 9.4 to $42 \mathrm{mg} / \mathrm{kg}$ at sampling location Pt. J.N. College (BRS5) from Power house 
sarvodaynagar (BRS6) in soil. Then concentration of $\mathrm{Pb}$ recorded was comparatively low in the soil. (Jayashree et al..2012) [10] studied heavy metal contamination in soil in an industrial zone and reported lead concentration $0.5-119 \mathrm{mg} / \mathrm{kg}$. In the present observation the mean concentration of Copper was found ranged between $0.1 \mathrm{mg} / \mathrm{kg}$ to $3.1 \mathrm{mg} / \mathrm{kg}$. The concentration of $\mathrm{Cu}$ recorded was low at sampling location Naraini (BCS2) and Kalyanpur (BCS4) in soil of study area. (Tripathi et al. 2015) [11] Studied soil of Vindhya Pradesh and reported copper concentration ranged from 0.1 to $87.0 \mathrm{mg} / \mathrm{kg}$. Iron concentration in the soil ranged from 15.7 to $70 \mathrm{mg} / \mathrm{kg}$. Iron is very insoluble under oxidizing condition in soil. (Akpoveta et al. 2010) [12] Studied physic-chemical characteristics and levels of some heavy metals in soil around metal scrap dumps in some parts of delta state, Nigeria and reported iron content 1411 to $1431 \mathrm{mg} / \mathrm{kg}$. In the present observation the mean concentration of copper was found to be ranging between 0.1 to $3.1 \mathrm{mg} / \mathrm{kg}$ in irrigated soil [13]. The concentration of $\mathrm{Cu}$ recorded was comparatively low 0.1 at sampling location Kalyanpur (BCS4). (In the present observation the mean concentration of $\mathrm{Mn}$ was found to be ranging between 0.5 Naraini (BCS2) to $11.5 \mathrm{mg} / \mathrm{kg}$ Pt. J.N. College (BRS5) in soil of study area.

Table2. Physico-chemical characteristic of soil collected from different areas of Banda City

\begin{tabular}{|c|c|c|c|c|c|c|c|c|c|c|c|c|}
\hline \multicolumn{2}{|c|}{ Parameter } & Temp & $\mathrm{pH}$ & $\begin{array}{c}\text { EC } \\
\text { mhos/cm }\end{array}$ & $\begin{array}{c}\mathrm{N} \\
\mathrm{mg} / \mathrm{kg}\end{array}$ & $\begin{array}{c}\mathrm{P} \\
\mathrm{mg} / \mathrm{kg}\end{array}$ & \begin{tabular}{c|}
$\mathrm{K}$ \\
$\mathrm{mg} / \mathrm{kg}$
\end{tabular} & $\begin{array}{c}\mathrm{Mn} \\
\mathrm{mg} / \mathrm{kg}\end{array}$ & $\begin{array}{c}\mathrm{Fe} \\
\mathrm{mg} / \mathrm{kg}\end{array}$ & $\begin{array}{c}\mathrm{Co} \\
\mathrm{mg} / \mathrm{kg}\end{array}$ & $\begin{array}{c}\mathrm{Cu} \\
\mathrm{mg} / \mathrm{kg}\end{array}$ & $\begin{array}{c}\mathrm{Pb} \\
\mathrm{mg} / \mathrm{kg}\end{array}$ \\
\hline \multirow{7}{*}{$\begin{array}{l}\text { Residential } \\
\text { Site }\end{array}$} & BRS1 & 28.2 & 7.0 & \begin{tabular}{|l|}
0.29 \\
\end{tabular} & 19.7 & 0.23 & 29.0 & 10.2 & 48.6 & 0.3 & 12.3 & 27.0 \\
\hline & BRS2 & 33.4 & 6.60 & 0.49 & 5.1 & 0.62 & 26.0 & 6.4 & 52.9 & 1.2 & 34.3 & 13.4 \\
\hline & BRS3 & 30.0 & 7.03 & 0.68 & 15.5 & 0.73 & 42.0 & 5.9 & 15.7 & 0.2 & 10.0 & 19.2 \\
\hline & BRS 4 & 25.7 & 6.38 & 0.79 & 7.3 & 0.34 & 35.0 & 9.2 & 55.0 & 2.0 & 7.9 & 21.5 \\
\hline & BRS 5 & 27.9 & 7.3 & 0.76 & 9.2 & 0.64 & 8.3 & 11.5 & 70.6 & 0.3 & 8.7 & 9.4 \\
\hline & BRS 6 & 31.0 & 7.3 & 0.73 & 14.3 & 0.36 & 10.5 & 3.7 & 36.6 & 2.5 & 8.4 & 42.0 \\
\hline & BRS 7 & 28.5 & 7.01 & 0.10 & 9.4 & 0.26 & 17.2 & 7.3 & 48.0 & 3.1 & 17.4 & 14.2 \\
\hline \multirow{7}{*}{$\begin{array}{l}\text { Cropland } \\
\text { Site }\end{array}$} & BCS1 & 30.0 & 7.88 & 0.56 & 14.3 & 0.85 & 18.5 & 7.2 & 40.9 & 1.8 & 9.6 & 26.0 \\
\hline & BCS2 & 31.5 & 7.39 & 0.47 & 5.14 & 0.75 & 27.0 & 0.5 & 86.4 & 0.6 & 12.2 & 11.2 \\
\hline & BCS3 & 27.0 & 6.8 & 0.92 & 27.3 & 0.59 & 35.4 & 4.6 & 48.8 & 0.5 & 10.5 & 15.3 \\
\hline & BCS4 & 26.8 & 7.0 & 0.40 & 21.4 & 0.65 & 26.0 & 1.5 & 36.5 & 0.1 & 14.6 & 32.4 \\
\hline & BCS5 & 29.2 & 7.7 & 0.59 & 11.2 & 0.49 & 17.3 & 7.3 & 49.2 & 1.5 & 19.6 & 32.7 \\
\hline & BCS6 & 30.3 & 7.03 & 0.86 & 29.5 & 0.23 & 41.7 & 2.3 & 42.0 & 2.3 & 24.5 & 18.3 \\
\hline & BCS 7 & 32.4 & 7.44 & 0.47 & 20.8 & 0.35 & 39.0 & 4.8 & 53.4 & 0.8 & 21.2 & 26.5 \\
\hline \multirow[t]{3}{*}{ Mean } & Mean & 29.421 & 7.133 & 0.579 & 15.010 & 0.506 & 26.636 & 5.886 & 48.900 & 1.229 & 15.086 & 22.079 \\
\hline & S.D. & 2.223 & 0.405 & 0.229 & 7.812 & 0.210 & 11.122 & 3.232 & \begin{tabular}{|l|}
16.339 \\
\end{tabular} & 0.978 & 7.602 & 9.44 \\
\hline & C.V. & 7.555 & \begin{tabular}{|l|}
5.677 \\
\end{tabular} & 39.55 & 52.045 & 41.501 & 41.755 & 54.91 & 33.413 & 79.576 & 50.391 & 42.796 \\
\hline
\end{tabular}

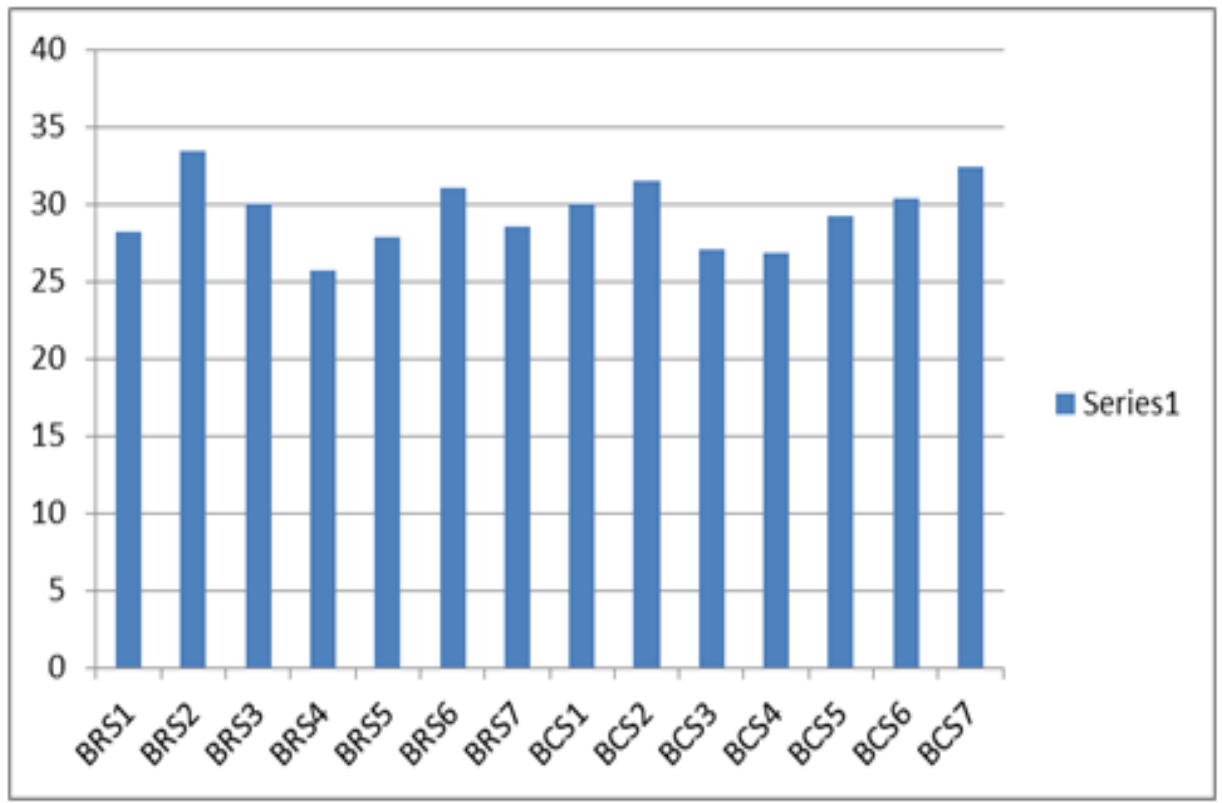

Fig1. Graphical representation of the Temperature 


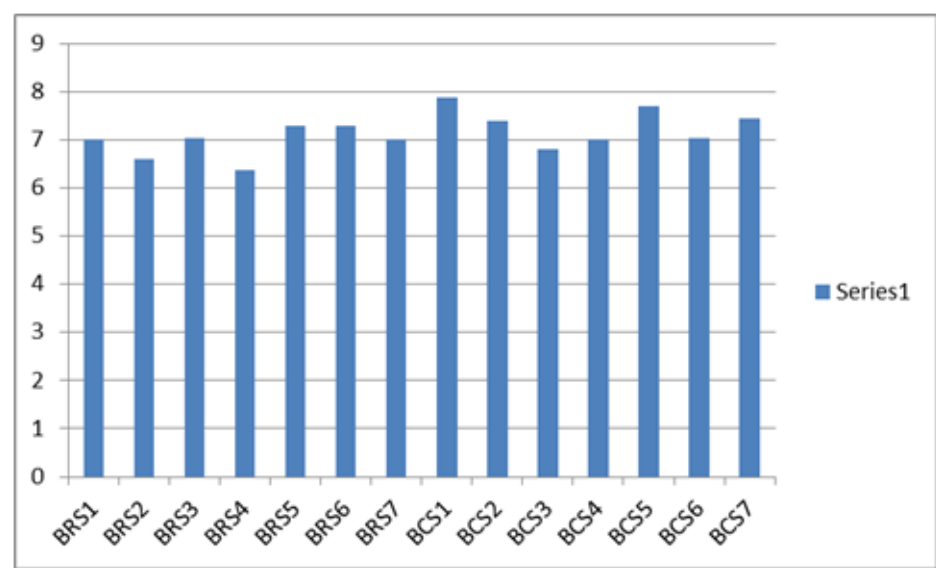

Fig2. Graphical representation of the $\mathrm{pH}$

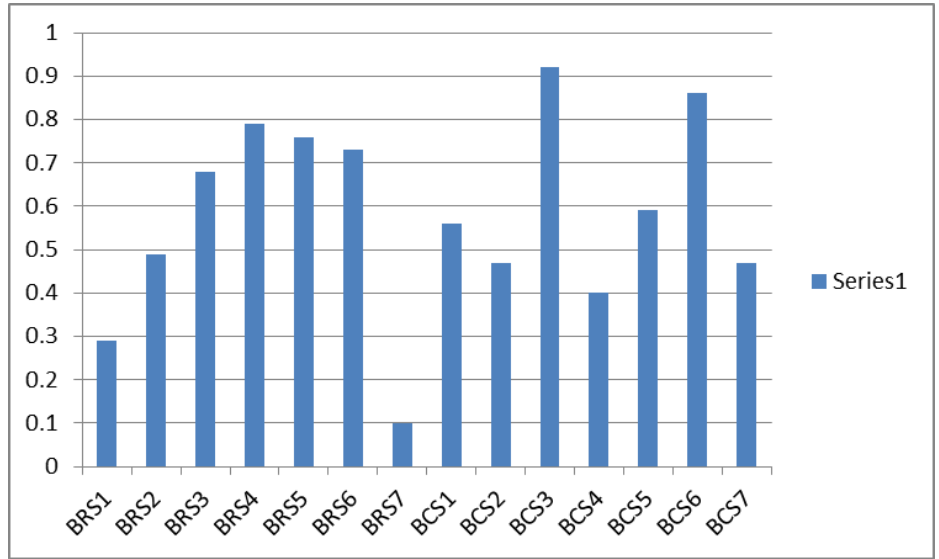

Fig3. Graphical representation of the EC

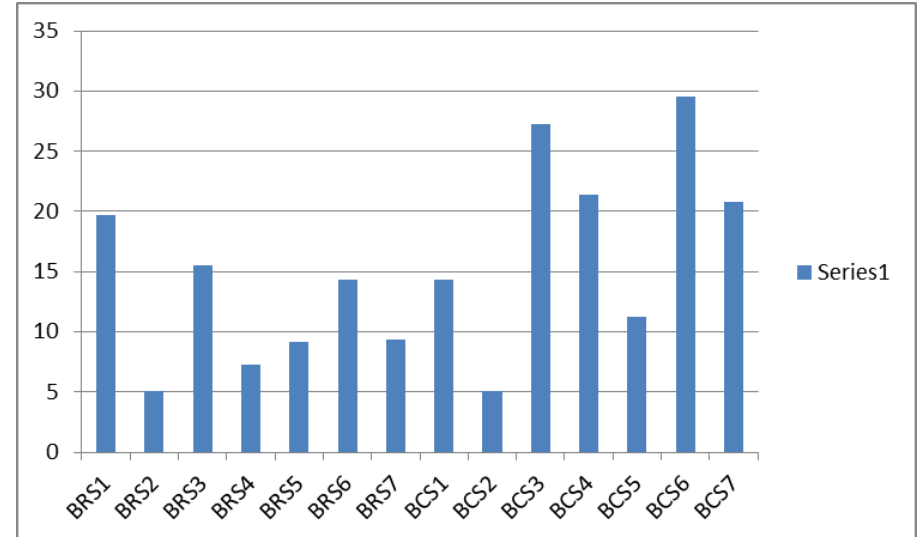

Fig4. Graphical representation of the $N$

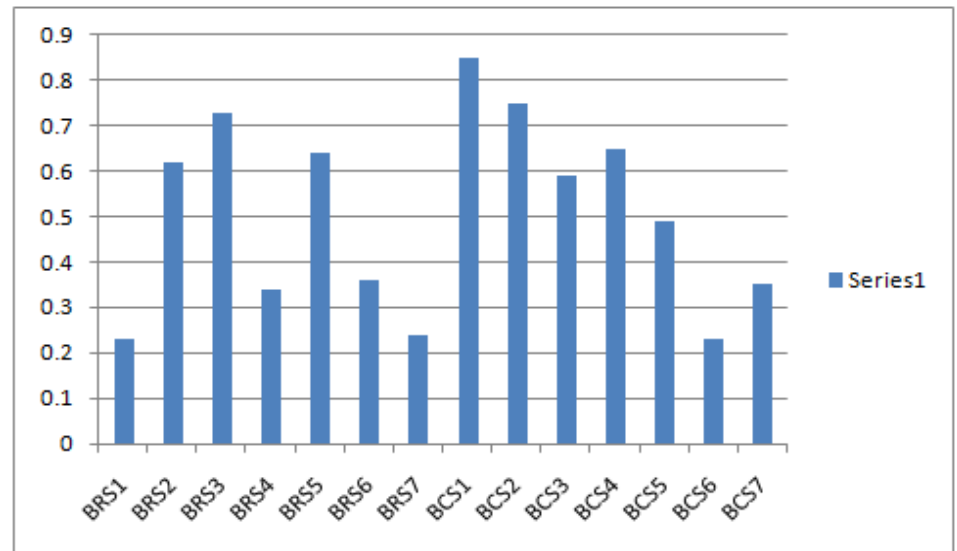

Fig5. Graphical representation of the $P$ 


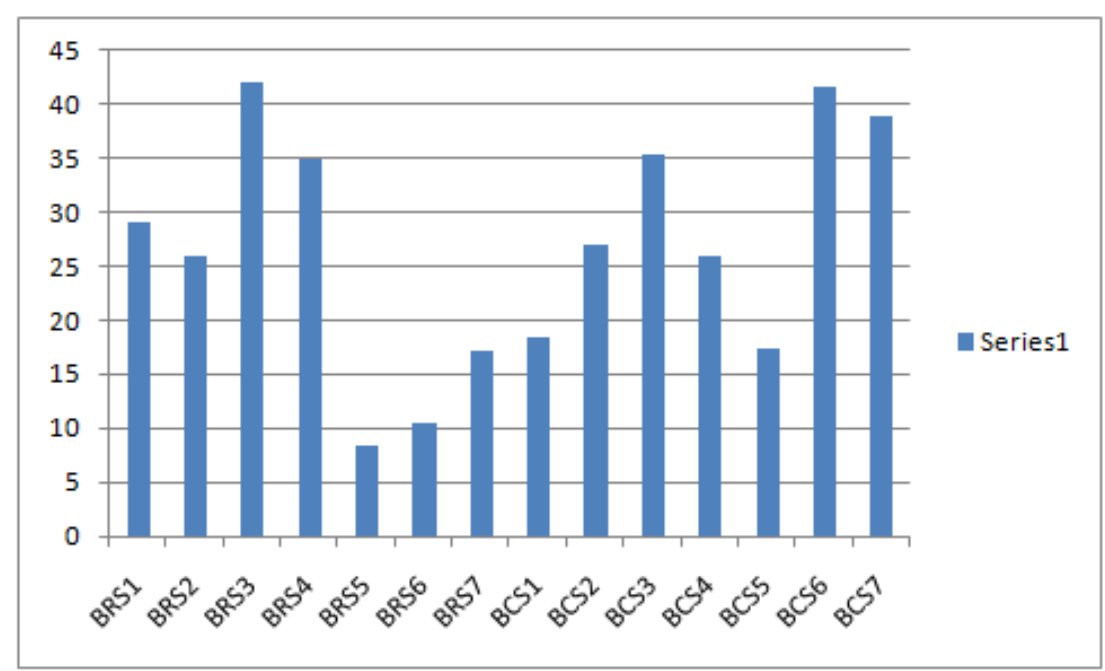

Fig6. Graphical representation of the $K$

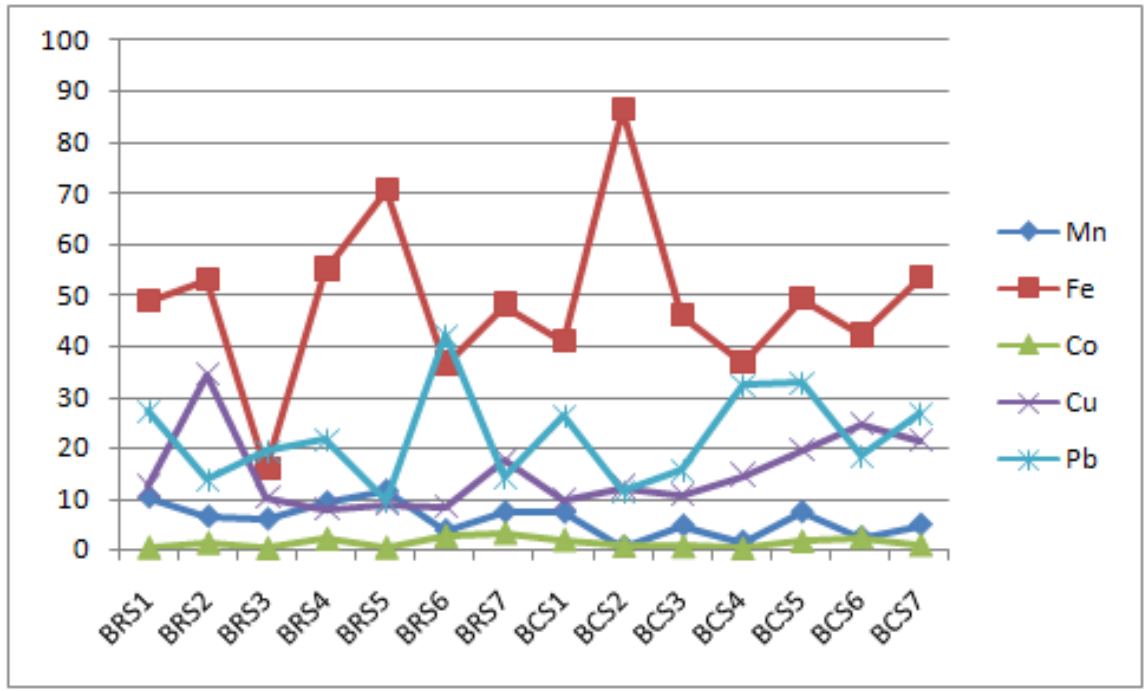

Fig7. Graphical representation of the Heavy Metals

\section{Conclusions}

Monitoring of micronutrients in the soil provides efficient way to assess him qualitative and quantitative difference in metal concentration at district locations. It can be concluded that the physico-chemical analysis of soil samples under study showed variable concentration of various parameters. Irregular distributions of micronutrients were recorded during the present investigation which may be attributed to the added fertilizers during the crop formation.

\section{REFERENCES}

[1] Arvind Prasad Dwivedi, Assessment of Physico-Chemical Quality of Soil in Rewa District of Madhya Pradesh ,International Journal of Advanced Research in Chemical Science, (2016); 3(11): 9-13.

[2] A.P. Dwivedi, I.P. Tripathi and M. Suresh Kumar, Assessment of Soil and Ground Water Quality in Rewa District of Vindhya Plateau (India), Journal Environment Sciences and Engs, (2013); 5(1) :51-54.

[3] Saar R.A and WeberJ.H. (1982) Environment Science and Technology (1982); 16:510-517.

[4] M. Anju, D.K. Banerjec. Multivariate Statistical Analysis of Heavy Metals in Soils of a Pb $-\mathrm{Zn}$ Mining area, India. Environ. Monit. Assess, DOI 10. 1007/s10661-011-2255-8, 2011.

[5] Piper C. S. A Laboratory Manual of Methods for the Examination of Soil and Determination of the Inorganic Consitate of Plant original edition 1942.Printed in India. Scientific Publisher Jodhpur (Raj.) India. 
[6] American public health association standard method for the examination of water and waste water $19^{\text {th }}$ E.d APHA Washington D.C1995.

[7] Indra Prasad Tripathi, Arvind Prasad Dwivedi, M. Suresh Kumar, Physico-Chemical Characteristic of Soil in Shahdol District of Vindhya Platue, Journal of Applicable Chemistry (2014); 3 (3): 1155-1164.

[8] D.K. Mandal, Deepti Agarkar and N.C. Khandare, Rationale of International land Evaluation Methods under Aberrant Climatic Conditions in Shrink- swell Soil of Indian Semiarid Tropics. Journal of Indian Society of soil Science, (2010); 58 (2): 141-146.

[9] Indra Prasad Tripathi, M. Suresh Kumar and Arvind Prasad Dwivedi, Concentration of Cr, Cd, $\mathrm{Ni}, \mathrm{Cu}$ and $\mathrm{Fe}$ in Soil of Umaria District, Vindhya Platue, India, International Journal of research Analysis and Evaluation, 2014;5(52):28- 32.

[10] Jayashree Deka and HP Sharma, Heavy Metal Contamination in Soil in an Industrial Zone and its Relation with some soil properties. Applied Science Research., (2012); 4 (2): 831-836.

[11] Indra Prasad Tripathi and Arvind Prasad Dwivedi,Heavy Metals Pollution in Soil of Vindhya Pradesh , India. Asian Academic Research Journal of Multidisciplinary, (2015); 1(30):627-638.

[12] OV Akpoveta, SA Osakwe, BE Okoh and BO Otuya, Physico- Chemical Characteristics and Levels of some Heavy Metals in Soil Around Metal Scrap Dumps in some Parts of delta state, Nigeria. Journal Appl. Sci. Environ. Manage. (2010); 14 (4): 57-60.

[13] P.K. Govil, J.E. Sorlie, N.N. Murthy, D. Sujatha, D. Reddy G.L.N., Rodolph-lund kim, Krishna, A.K. and K. Rama Mohan, Soil Contamination of Heavy Metals in the Katedan Industrial development Area, Hyderabad, India; Journal of Environment Assess.140:313-323. 